\title{
Drain site hernia in adult - case report and review of literature
}

\author{
Irpatgire $\mathbf{R}^{1}$, Sarda $V^{2}$, Kale $D^{3}$ \\ ${ }^{1}$ Dr Ravindra Irpatgire, Associate Professor, ${ }^{2}$ Dr Vikram Sarda, Assistant Professor, ${ }^{3}$ Dr Dinkar Kale, Professor; all \\ authors are affiliated with Department of General Surgery, MIMSR Medical College Latur, Maharashtra, India.
}

Address for Correspondence: Dr. Irpatgire Ravindra, Department of General Surgery, MIMSR Medical College Latur, Maharashtra, India. E-mail address: rirpatgire@rediffmail.com

\begin{abstract}
Hernia is a very common surgical problem. Drain site hernias are very rare (0.1-3.4 \%) incidence quoted in literature. We report the case of a 40year old male who presented with a swelling in the right lower abdomen. CT scan revealed herniation of small bowel with interstitial spread through a former drain site placed after a previous laparotomy 10 years back.
\end{abstract}

Keywords- Drain, Complications, Hernia, small bowel

\section{Introduction}

Intraperitoneal drains are frequently placed to drain the post-operative collections. The routine use of drains for abdominal surgical interventions has become less common because of variety of post drainage complications. These complications include infection, pain, breakage, hemorrhage, tissue damage, blockage and herniation of viscera [1] [2]. Small bowel herniation through drain site is very rare long term complication of intraperitoneal drain placement. We report a case of irreducible hernia through drain site in 40 year old male.

\section{Case Report}

A40 year old male presented with pain and bulge in the right lower quadrant of the abdomen since 4 weeks. He had an emergency laparotomy for small bowel enteric perforation 10 yrs back. During that admission he had intrperitoneal drain

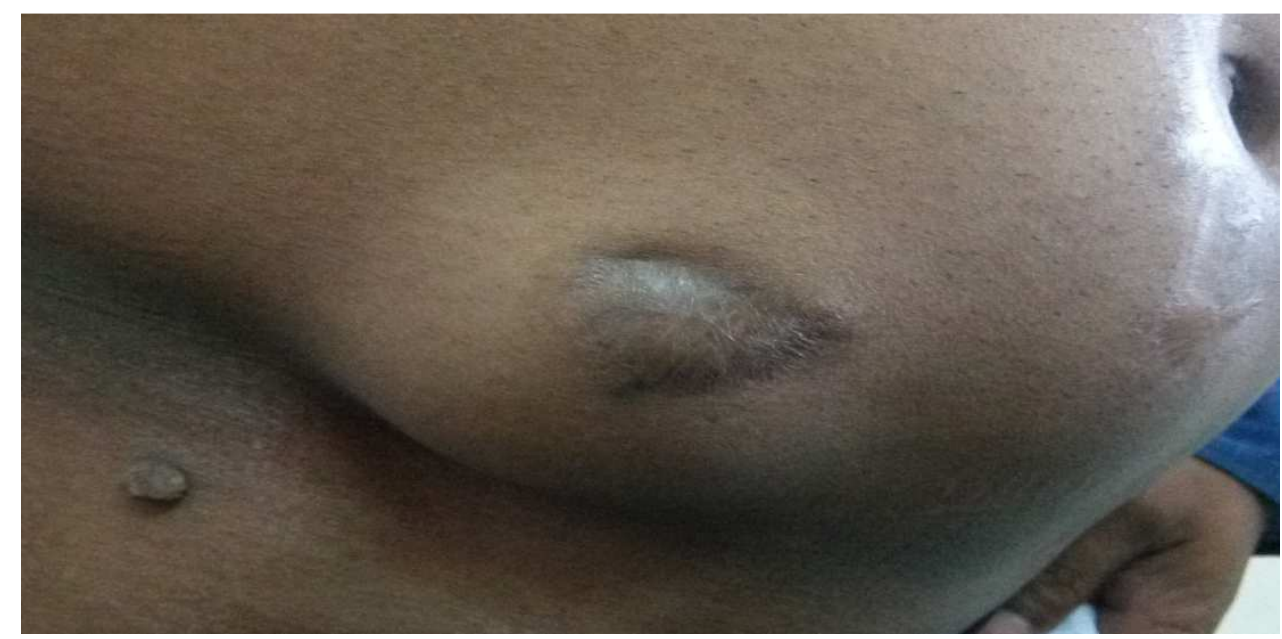

Figure-1: Preoperative image showing bulge at previous drain site

Manuscript received $16^{\text {th }}$ October 2016

Reviewed: $28^{\text {th }}$ October 2016

Author Corrected: $15^{\text {th }}$ November 2016

Accepted for Publication $27^{\text {th }}$ November 2016 
insertion at the same site of bulge. He noticed the bulge in right lower quadrant 3 months after laparotomy. To start with bulge was painless and reducible. Since last one month bulge has become painful and irreducible. On clinical examination vitals were stable. On examination ill-defined irreducible mass noted at the previous drain site. (Figure-1) Laboratory investigations were normal. CT abdomen showed a defect at the drain site and herniation of small bowel with interstitial spread (Figure-2). On exploration a defect of around $3 \mathrm{~cm}$ noted which was closed with prolene suture.(Figure3 ) An onlay prolene mesh repair was done. Postoperative period was uneventful.

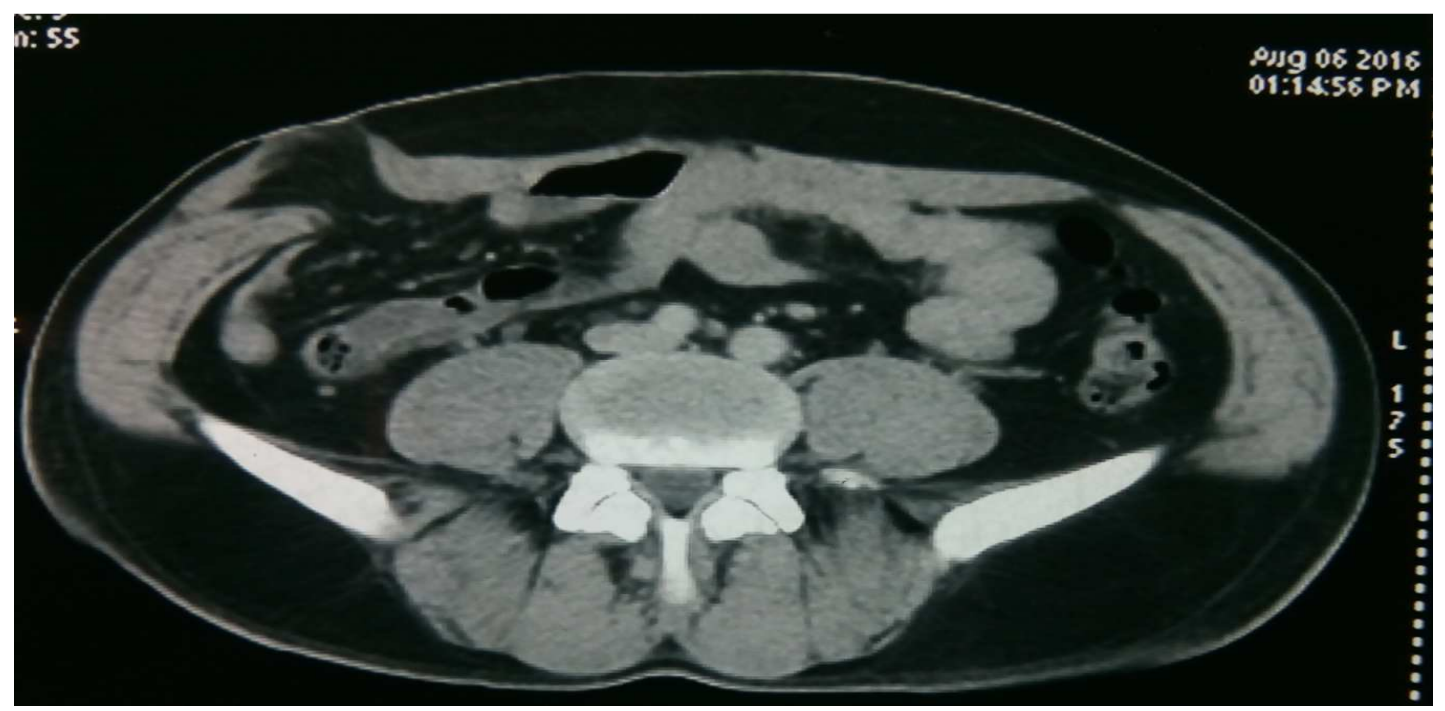

Figure-2: CT Scan showing defect in the anterior abdominal wall

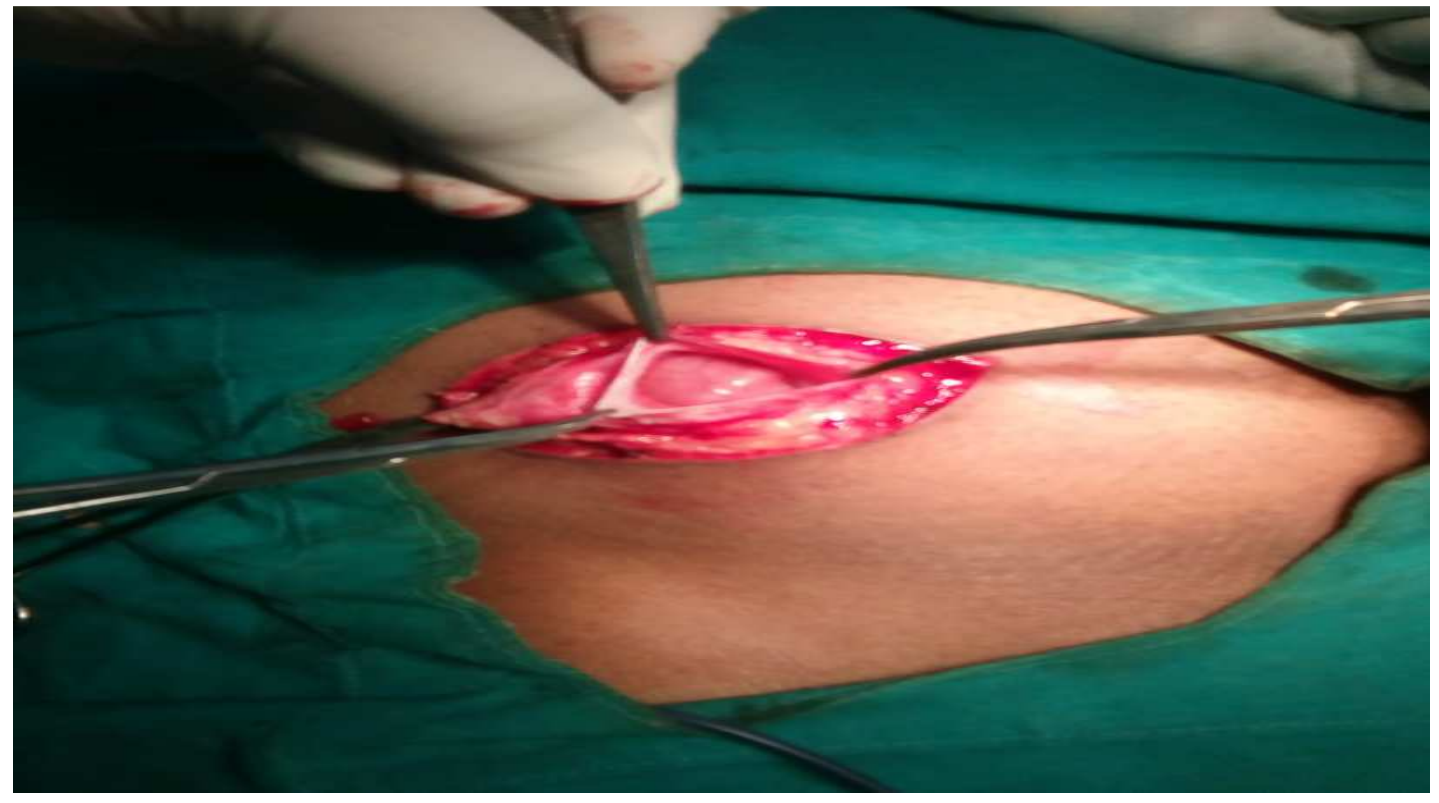

Figure-3: Intraoperative image showing defect

\section{Discussion}

Drain site hernia is very rare long term complication of drain insertion [3] Previous reports quoted the incidence rate of $0.1-3.4 \%$ [4]. Drain site hernias are more common after post open as compared to post laparoscopic surgery. Content of the hernia is usually omentum and small bowel [5]. Morbidity and mortality is usually because of strangulation of the small bowel. Appendix, gallbladder have been reported as content of the drain site hernia [6] [7]. Large size of the drain $(>10 \mathrm{~mm})$, surgical site infection, obesity, increased intraabdominal pressure, steroid administration has been prominent predisposing factors [5] [8]. Incidence 
of port site hernia following laparoscopic surgery reported to be $0.65 \%-2.5 \%$ [9]. Probably the same factors which cause port site hernia govern herniation from surgical drain site following open surgery.

Various suggestions have been made by previous reports on prevention of drain site hernia. These include use of drain size less than $10 \mathrm{~mm}$ external diameter, oblique or transverse insertion through abdominal wall, obliteration of the tract with non absorbable suture after removal and shortening of the drain progressively before it is removed [5] [10]. In laparoscopic surgery drain should be placed through the port size less than $5 \mathrm{~mm}$. If for any specific reason drain is placed through larger size port single narrowing facial stitch or purse string suture is recommended [11].

\section{Conclusion}

Use of intraperitoneal drain should be minimized as potential complications can cause significant morbidity. If drain is absolutely required it should be inserted and removed by strictly adhering principles of proper insertion and removal.

\section{Funding: Nil, Conflict of interest: None. \\ Permission of IRB: Yes \\ Ethical approval: Not required}

\section{References}

1. Nomura T, Shirai Y, Okamoto H, Hatakeyama K. Bowel perforation caused by silicone drains: a report of two cases. Surg Today. 1998;28(9):940-2.

2. M. Kawai, M. Tani, H. Terasawa et al., "Early removal of prophylactic drains reduces the risk of intraabdominal infections in patients with pancreatic head resection: prospective study for 104 consecutive patients," Annals of Surgery. 2006;244(1):1-7.
3. A. Loh and P. A. Jones, "Evisceration and other complications of abdominal drains," Postgraduate Medical Journal, vol. 67, no. 789, pp. 687-688, 1991.

4. Makama JG, Ameh EA. Surgical drains: what the resident needs to know. Niger J Med. 2008 Jul-Aug; 17(3):244-50.

5. Joong JY, Seung HL, Byung KA, Sung UB. Strangulated small bowel hernia through a drain site. J Korean Surg Soc 2007; 73: 447-448.

6. N. Duraker, K. Buy“ ukas “. „ik, and Y. Helvacioglu, "Drain site evisceration of the appendix: report of a case," Surgery Today, vol. 27, no. 7, pp. 651-652, 1997.

7. Vedat B, Aziz S, Cetin K. Evisceration of gallbladder at the site of a Pezzer drain: a case report. Cases J. 2009 Jul 31;2:8601. doi: 10.4076/1757-1626-2-8601.

8. Lee R, Raftery AT. Evisceration of small bowel at the site of an intra-abdominal drain. A complication of steroid therapy? Br J Clin Pract. 1982 Jul-Aug; 36 (7-8):282-3.

9. Tonouchi H, Ohmori Y, Kobayashi M, Kusunoki M. Trocar site hernia. Arch Surg. 2004 Nov;139(11): 1248-56.

10. O'Riordan DC, Horgan LF, Davidson BR. Drain-site herniation of the appendix. Br J Surg. 1995 Dec; 82(12): 1628.

11. Nadler RB, McDougall E, Bullock AD, Ludwig MA, Brunt LM. Fascial closure of laparoscopic port sites: a new technique. Urology. 1995 Jun;45(6):1046-8.

\section{How to cite this article?}

Irpatgire R, Sarda V, Kale D. Drain site hernia in adult - case report and review of literature. Int J Med Res Rev 2016;4(11):1982-1984.doi:10.17511/ijmrr. 2016.i11.14. 